MaPan : Jurnal Matematika dan Pembelajaran

p-ISSN: 2354-6883 ; e-ISSN: 2581-172X

Volume 6, No 2, December 2018 (237-249)

DOI: https://doi.org/10.24252/mapan.2018v6n9

\title{
KEMAMPUAN KONEKSI MATEMATIS SISWA SEKOLAH MENENGAH PERTAMA BERDASARKAN GAYA KOGNITIF
}

\author{
Maulidyah Firdausi'), Siti Inganah'), Alfiani Athma Putri Rosyadi'3) \\ 1,2,3Universitas Muhammadiyah Malang \\ 1,2,3Jalan Raya Tlogomas No. 246 Malang \\ Email: firdausimaulidyah@gmail.com ${ }^{1)}$, singanah@gmail.com²), \\ athmaputri@gmail.com ${ }^{3}$ )
}

Submitted: 17-09-2018, Revised: 03-10-2018, Accepted: 08-12-2018

\begin{abstract}
Abstrak:
Tujuan penelitian ini adalah mendeskripsikan kemampuan koneksi matematis siswa sekolah menengah pertama yang ditinjau dari gaya kognitif Field Dependent (FD), Field Intermediate (FDI), dan Field Independent (FI). Subjek penelitian ini adalah adalah siswa SMP Negri 3 Batu kelas VIII-G berjumlahkan 26 siswa yang dikelompokkan berdasarkan gaya kognitif yang dimiliki oleh setiap siswa, setiap kelompok gaya kogitif diambil perwakilan 2 subjek dengan menggunakan metode purposive sampling untuk diukur kemampuan koneksi matematisnya. Berdasarkan hasil penelitian ini kemampuan koneksi matematis yang dimiliki oleh setiap siswa berbeda-beda. Subjek dengan kelompok gaya kognitif Field Independent (FI) memiliki perbedaan kemampuan koneksi matematis, salah satu subjek dapat memenuhi semua indikator dan subjek lainnya hanya memenuhi beberapa kemampuan koneksi matematis. Hal ini menunjukkan bahwa subjek yang termasuk dalam kelompok gaya kognitif yang sama belum tentu memiliki kemampuan koneksi yang sama. Subjek dengan kelompok gaya kognitif Field Intermediate (FDI) hanya memenuhi beberapa indikator kemampuan koneksi matematis. Subjek dengan gaya kognitif Field Dependent (FD) belum dapat memenuhi semua indikator kemampuan koneksi matematis. Hal ini menunjukkan bahwa subjek yang memiliki gaya kognitif yang sama belum tentu memiliki kemampuan koneksi matematis yang sama juga.
\end{abstract}

Kata Kunci: Kemampuan Koneksi Matematis, Gaya Kognitif

\section{THE ABILITY CONNECTION MATHEMATICAL OF JUNIOR HIGH SCHOOL STUDENTS BASED ON COGNITIVE STYLE}

\begin{abstract}
:
The objective of this study is to describe the mathematical connection ability of junior high school students in terms of the cognitive styles of Field Dependent (FD), Field Intermediate (FDI), and Field Independent (FI). The subjects of this study were the students of State Junior High School 3 Batu of class VIII-G consisting of 26 students who were grouped based on the cognitive style possessed by every student. The study used purposive sampling technique for selecting the sample by taking 2 representative students from every cognitive style group to measure their mathematical connection abilities. The findings show that the students' mathematical connection abilities are different each other. The students from Field Independent (FI) cognitive
\end{abstract}


style group have different mathematical connection abilities, one student can fulfill all indicators and the other one only fulfills some mathematical connection abilities. It can be inferred that the students who have the same cognitive style group do not necessarily have the same connection ability. The students with Field Intermediate (FDI) cognitive style group only fulfill several indicators of mathematical connection ability. The students with Field Dependent (FD) cognitive style cannot fulfill all indicators of mathematical connection ability. It indicates that the students who have the same cognitive style do not necessarily have the same mathematical connection abilities as well.

Keywords: Mathematical Connection Ability, Cognitive Style

How to Cite: Firdausi, M., Inganah, S., \& Rosyadi, A. A. P. (2018). Analisis Kemampuan Koneksi Matematis Siswa Sekolah Menengah Pertama Ditinjau dari Gaya Kognitif. MaPan : Jurnal Matematika dan Pembelajaran, 6(2), 237-249.

$\mathrm{P}$ embelajaran matematika merupakan pembelajaran yang penting, karena dalam kehidupan sehari-hari kita tidak akan terlepas dari penggunaan matematika mulai dari permasalahan yang sederhana sampai dengan yag rumit. Mata pelajaran matematika perlu diajarkan untuk membekali siswa dalam berpikir logis, analitis, sistematis, kritis, dan kreatif serta kemampuan dalam bekerja sama. Siswa mampu menghubungkan antar konsep matematika, menghubungkan antar topik, menghubungkan matematika dengan bidang lainnya, serta mengubungkan matematika dalam kehidupan sehari-hari maka pembelajaran matematika dikatakan bermakna (Sugiarti \& Basuki, 2014).

Konsep-konsep dalam matematika saling berkaitan, terlihat ketika mempelajari suatu konsep perlu memperhatikan konsep sebelumnya yang telah dipelajari. Apabila siswa tidak memahami suatu konsep maka mereka akan kesulitan untuk menerima konsep selanjutnya, hal ini yang menyebabkan siswa memiliki kemampuan yang rendah dalam mengaitkan antar konsep dalam matematika (Yanirawati, Nilawasti, \& Mirna, 2012).

Kemampuan dalam memandang keterkaitan antar konsep pada matematika secara internal yakni matematika dengan matematika dan secara eksternal matematika dengan bidang lain atau kehidupan nyata dapat dikatakan sebagai kemampuan koneksi matematis (Yanirawati et al., 2012). Koneksi matematika sangat penting dimiliki bagi setiap siswa karena akan membantu membentuk pemahaman siswa dalam mengetahui bahwa matematika sebagai penggabungan dengan kehidupan sehari-hari (Kusmanto \& Marliyana, 2014). Kemampuan koneksi matematis harus dikuasai siswa pada saat belajar matematika karena nantinya siswa dapat melihat bahwa matematika merupakan ilmu yang topiknya saling berkaitan serta dapat 
bermanfaat dikehidupan dan dalam mempelajari pelajaran lainnya (Sugiman, 2008).

National Council of Teachers of Mathematics menjelaskan bahwa koneksi merupakan kemampuan siswa dalam menghubungkan dan memahami bagaimana ide matematika saling berhubungan serta menerapkan matematika dengan konteks di luar matematika (National Council of Teachers Mathematics, 2000). Matematika bukan rangkaian kemampuan dan konsep yang terpisah sehingga konsep yang telah dipelajari dapat digunakan untuk memahami konsep lainnya (Romli, 2016). Koneksi dapat menjadikan siswa menciptakan pemahaman baru yang berhubungan dengan pengetahuan sebelumnya yang telah mereka terima (National Council of Teachers Mathematics, 2000).

Hasil wawancara yang telah dilakukan dengan salah satu guru matematika di SMP Negeri 3 Batu, bahwa ada beberapa siswa terkadang lupa dengan materi yang telah dipelajari sebelumnya dan perlu dibimbing dalam menyelesaikan masalah matematis atau masalah yang berhubungan dengan matematika. Model pembelajaran yang dilakukan oleh guru di sekolah adalah ceramah dan pemberian latihan soal kepada siswa. Siswa sering mengalami kesulitan pada saat dihadapkan dengan sebuah soal yang dalam penyelesaiannya membutuhkan beberapa konsep, misalnya soal aritmatika yang dalam penyelesaiannya menggunakan beberapa konsep yakni aljabar dan aritmatika. Beberapa siswa dalam mengerjakan soal cerita terkadang tidak menuliskan apa yang diketahui dan apa yang ditanyakan dari soal dan setelah selesai melakukan perhitungan siswa juga sering lupa untuk menulis kesimpulan dari hasil pekerjaannya. Hasil wawancara dengan guru tersebut terlihat bahwa setiap siswa memiliki kemampuan dalam hal berpikir dan menyelesaikan masalah yang berbeda-beda. Faktor yang menyebabkan peserta didik memiliki kemampuan yang berbeda beda salah satunya adalah karena gaya kognitif yang dimiliki tiap siswa yang juga berbeda-beda.

Gaya kognitif merupakan salah satu bagian dari kemampuan pemecahan masalah dalam matematika (Ulya, Kartono, \& Retnoningsih, 2014). Cara seseorang dalam menangani, membenahi, dan memanfaatkan informasi untuk menjawab atau menyelesaikan suatu masalah atau berbagai situasi jenis lingkungannya juga dapat dikatakan sebagai gaya kognitif (Ngilawajan, 2013). Gaya kognitif menggambarkan karakteristik siswa seperti sikap, motivasi, minat dan kemampuan berpikir (Usodo, 2011). Jadi gaya kognitif merupakan karakter individu dalam merespons segala informasi yang diterimanya. 
Terdapat dua klasifikasi dari gaya kognitif yakni Field Dependent (FD) dan Field Independent (FI) (Witkin, Moore, Goodenough, \& Cox, 1977). Gaya kognitif terdapat pula bentuk gabungan antara Field Dependent (FD) dan Field Independent (FI) yakni Field Intermediate (FDI) (Guisande, Paramo, Tinajero, \& Almeida, 2007). Siswa yang termasuk tipe Field Dependent (FD) cenderung memerlukan interuksi yang lebih jelas dari orang lain dalam menyelesaikan masalah, sedangkan siswa dengan tipe Field Independent (FI) bekerja dengan mandiri dan mengevaluasi masalah dengan kritis (Yousefi, 2011). Siswa dengan tipe Field Intermediate (FDI) memiliki kemampuan seperti Field Dependent (FD) dan Field Independent (FI) (Guisande et al., 2007).

Hasil penelitian dari Sari (2017) menjelaskan bahwa siswa dengan gaya kognitif Field Independent (FI) mampu menghubungkan permasalahan yang telah diberikan dengan materi yang telah dipelajari, menyelesaikan permasalahan sesuai prosedur, dan siswa juga mampu menghubungkannya dengan ilmu lain. Siswa dengan gaya kognitif Field Dependent (FD) menjelaskan siswa mampu menghubungkan permasalahan yang diberikan dengan materi yang telah dipelajari dan dapat menghubungkannya dengan ilmu lain akan tetapi belum dapat menyelesaikan permasalahan dengan benar karena melakukan kesalahan dalam perhitungan.

Setiap gaya kognitif baik Field Dependent (FD), Field Intermediate (FDI), dan Field Independent (FI) memiliki kemampuan dalam menyelesaikan masalah yang berbeda-beda. Perbedaan dari ketiga gaya kognitif tersebut dapat mempengaruhi kemampuan koneksi matematis yang dimiliki oleh setiap siswa. Berdasarkan permasalahan tersebut, maka tujuan dalam penelitian ini adalah untuk mendeskripsikan kemampuan koneksi matematis yang dimiliki oleh siswa jika ditinjau dari gaya kognitif Field Dependent (FD), Field Intermediate (FDI), dan Field Independent (FI).

\section{METODE PENELITIAN}

Penelitian ini menggunakan pendekatan penelitian kualitatif dan termasuk jenis penelitian deskriptif. Subjek yang diambil dalam penelitian ini adalah 26 siswa di SMP Negeri 3 Batu kelas VIII-G untuk mengikuti tes Group Embedded Figure Test (GEFT) yang akan di kelompokan dalam tiap gaya kognitif Field Dependent (FD), Field Intermediate (FDI), dan Field Independent (FI). Subjek kemudian diambil sebanyak 2 siswa dari setiap perwakilan kelompok gaya kognitif Field Dependent (FD), Field Intermediate (FDI), dan Field Independent (FI) 
dengan menggunakan metode purposive sampling untuk mengikuti tes kemampuan koneksi matematis dan wawancara.

Instrumen yang digunakan dalam penelitian ini adalah tes Group Embedded Figure Test (GEFT), tes kemampuan koneksi matematis dan wawancara. Tes Group Embbeded Figure Test (GEFT) ini dikembangkan oleh Witkin dkk. (1977) siswa diarahkan untuk mencari serangkaian bentuk sederhana yang terdapat dalam bentuk yang lebih kompleks. Tes GEFT terdiri dari tiga bagian. Bagian yang pertama terdiri dari 7 soal yang dikerjakan dengan waktu 3 menit sedangkan untuk bagian dua dan tiga terdiri dari 9 soal dan dikerjakan selama 6 menit tiap bagiannya. Penilaian pada test GEFT ini hanya pada bagian ke dua dan tiga, pada bagian yang pertama digunakan untuk latihan sehingga siswa bisa mengerjakan tes ini dengan jelas. Menurut Idris (Ulya, 2015) skor dalam pengelompokan gaya kognitif siswa berdasarkan tes GEFT dikategorikan pada tabel 1 berikut:

Tabel 1. Pedoman Pengelompokan Gaya Kognitif

\begin{tabular}{cc}
\hline Skor Test GEFT & Gaya Kognitif \\
\hline $0-7$ & Field Dependent (FD) \\
\hline $8-13$ & Field Intermediate (FDI) \\
\hline $14-18$ & Field Independent (FI)
\end{tabular}

Tes kemampuan koneksi matematis dalam penelitian ini bertujuan untuk mengukur kemampuan koneksi subjek berdasarkan indikator yang telah ditentukan.Indikator yang digunakan untuk mengkur kemampuan koneksi matematis pada penelitian ini terlihat pada tabel 2 berikut :

Tabel 2. Indikator Kemampuan Koneksi Matematis

\begin{tabular}{ll}
\hline \multicolumn{1}{c}{$\begin{array}{l}\text { Indikator } \\
\text { Kemampuan Koneksi Matematis }\end{array}$} & \multicolumn{1}{c}{$\begin{array}{c}\text { Deskripsi Indikator Kemampuan } \\
\text { Koneksi Matematis }\end{array}$} \\
\hline Mengenali dan menggunakan & Siswa mampu mengenali ide \\
hubungan antar ide pada & dengan menuliskan apa yang \\
matematika & diketahui dan apa yang ditanyakan \\
dalam menyelesaikan masalah & Siswa mampu menggunakan ide \\
& untuk membuat model matematika \\
& dalam menyelesaikan masalah \\
\hline Memahamin bagaimana ide-ide & Siswa mampu membuat hubungan \\
matematika saling berkaitan & antara konsep yang satu dengan \\
\hline
\end{tabular}




\begin{tabular}{ll}
\hline & $\begin{array}{l}\text { konsep lainnya dalam } \\
\text { menyelesaikan masalah }\end{array}$ \\
\hline Memahami hubungan matematika & $\begin{array}{l}\text { Siswa mampu mengartikan masalah } \\
\text { dengan kehidupan sehari-hari }\end{array}$ \\
& matematika \\
& Siswa menerapkan konsep dalam \\
& menyelesaikan permasalahan \\
& kehidupan nyata \\
\hline (National Council of Teachers Mathematics, 2000)
\end{tabular}

Tes kemampuan koneksi ini, siswa dihadapkan dengan dua butir soal berupa soal cerita yang berkaitan dengan kehidupan sehari-hari yang dikerjakan dengan waktu 60 menit. Setiap soal pada tes kemampuan koneksi matematis memuat beberapa materi yakni aljabar, statistika, bangun datar, dan persentase.

Wawancara yang dilakukan dalam penelitian ini memiliki tujuan untuk memperkuat hasil yang didapat dari tes kemampuan koneksi matematis setiap subjek. Wawancara ini ditujukan agar dapat mengetahui keaslian dan secara rinci jawaban atau bagaimana subjek dapat menyelesaikan permasalahan. Wawancara dalam penelitian ini sifatnya semi terstruktur.

Penyajian data yang digunakan dalam penelitian ini adalah berupa uraian yang disusun berdasarkan hasil tes dan wawancara yang telah dilakukan oleh subjek. Pemaparan data dilakukan dengan mengelompokkan dan mengidentifikasi data yang telah diperoleh. Peneliti melakukan pengamatan dan menelaah terhadap hasil tes tulis, data tersebut nantinya akan dideskripsikan pada setiap langkah-langkah subjek dalam menyelesaikan masalah kemampuan koneksi matematis, tes wawancara berdasarkan gaya kognitif yang sudah ditentukan.

\section{HASIL PENELITIAN DAN PEMBAHASAN}

Berdasarkan skor tes GEFT kelas VIII-G SMP Negeri 3 Batu, didapatkan bahwa didalam kelas tersebut terdapat 8 subjek yang dikelompokkan dalam gaya kognitif Field Independent (FI), 14 subjek dikelompokkan dalam gaya kognitif Field Intermediate (FDI) dan 4 subjek di kelompokan dalam gaya kognitif Field Dependent (FD). Subjek diambil lagi dengan menggunakan metode purposive sampling sebanyak dua subjek dari setiap kelompok gaya kognitif untuk diukur kemampuan koneksi matematisnya. Subjek kelompok gaya 
kognitif Field Independent (FI)adalah subjek SM dan RWA. Subjek kelompok gaya kognitif Field Intermediate (FDI) adalah CN dan KA. Subjek dengan kelompok gaya kognitif Field Dependent (FD) adalah SW dan ID.

Subjek SM yang termasuk dalam kelompok gaya kognitif Field Independent (FI) dapat memenuhi indikator kemampuan koneksi matematis yang pertama yakni mengenali ide dan menggunakan ide untuk membuat model matematika. Menyebutkan apa yang diketahui dan apa yang ditanyakan pada soal. Membuat model matematika terlebih dahulu sebelum mengerjakan soal agar dapat mempermudah subjek dalam menyelesaikan soal. Subjek dapat memenuhi indikator kemampuan koneksi matematis yang kedua yakni membuat hubungan antar konsep yang satu dengan konsep yang lainnya dalam menyelesaikan masalah dilihat dari langkah-langkah yang diambil dalam menyelesaikan kedua soal sudah benar dan sistematis. Hasil dari jawaban terlihat bahwa dapat memahami konsep hitung aljabar, keliling persegi panjang, luas persegi panjang dan jajar genjang, persentase, dan mean pada statistika. Subjek dapat memenuhi indikator kemampuan koneksi matematis yang ketiga yakni memahami hubungan matematika dengan kehidupan sehari-hari, yakni subjek dapat mengartikan dan memahami soal yang berhubungan dengan kehidupan nyata atau sehari-hari.

Subjek RWA yang termasuk dalam kelompok gaya kognitif Field Independent (FI) dapat memenuhi indikator kemampuan koneksi matematis yang pertama yakni mengenali ide dan menggunakan ide untuk membuat model matematika. Menyebutkan apa yang diketahui dan apa yang ditanyakan pada soal. Membuat model matematika terlebih dahulu sebelum mengerjakan soal agar dapat mempermudah subjek dalam menyelesaikan soal. Subjek belum dapat memenuhi indikator kemampuan koneksi matematis yang kedua yakni membuat hubungan antar konsep yang satu dengan konsep yang lainnya dalam menyelesaikan masalah, dilihat dari langkah-langkah yang diambil dalam menyelesaikan soal pertama sudah benar dan sistematis sedangkan pada soal kedua langkah awal yang diambil sudah benar tapi belum dapat menyelesaikan dengan benar karena masih mengalami kesalahan dalam perhitungan. Hasil dari jawaban terlihat bahwa dapat memahami konsep keliling persegi panjang, luas persegi panjang dan jajar genjang, persentase, dan mean pada statistika tetapi kurang memahami konsep hitung aljabar. Subjek dapat memenuhi indikator kemampuan koneksi matematis yang ketiga yakni memahami hubungan matematika dengan kehidupan sehari-hari, dalam hal ini 
subjek dapat mengartikan dan memahami soal yang berhubungan dengan kehidupan nyata atau sehari-hari.

Subjek penelitian yang dikelompokkan dalam gaya kognitif yang sama belum tentu memiliki kemampuan yang sama. Subjek yang dikelompokkan dalam gaya kognitif Field Independent (FI) memiliki perbedaan antara subjek SM dan RWA. Subjek SM dapat mencapai indikator memahami bagaimana ide-ide matematika saling berkaitan tersebut sedangkan RWA belum dapat mencapainya. Hal ini mendukung hasil penelitian Fajriyah dan Suseno (2014) yang menunjukkan bahwa kategori subjek dengan gaya kognitif yang sama tidak selalu memiliki kemampuan dalam memecahkan masalah yang sama pula. Penelitian Sari, Yusmin, dan Nursangaji (2018) menjelaskan bahwa kemampuan koneksi yang dimiliki oleh kelompok gaya kognitif Field Independent (FI) tidak semua subjek yang termasuk dalam kelompok tersebut dapat memenuhi semua indikator koneksi matematis.

Subjek CN yang termasuk dalam kelompok gaya kognitif Field Intermediate (FDI) dapat memenuhi indikator kemampuan koneksi matematis yang pertama yakni mengenali ide dan menggunakan ide untuk membuat model matematika. Menyebutkan apa yang diketahui dan apa yang ditanyakan pada soal. Membuat model matematika terlebih dahulu sebelum mengerjakan soal agar dapat mempermudah dalam menyelesaikan soal. Subjek belum dapat memenuhi indikator kemampuan koneksi matematis yang kedua yakni membuat hubungan antar konsep yang satu dengan konsep yang lainnya dalam menyelesaikan masalah dilihat dari langkah-langkah yang diambil subjek dalam menyelesaikan kedua soal sudah benar dan sistematis tetapi subjek masih mengalami kesalahan dalam menghitung. Hasil dari jawaban menunjukkan bahwa dapat memahami konsep keliling persegi panjang, luas persegi panjang dan jajar genjang, persentase, dan mean pada statistika tetapi belum memahami konsep operasi hitung aljabar karena mengalami kesalahan perhitungan pada bagian operasi hitung aljabar dalam mengerjakan kedua soal. Subjek dapat memenuhi indikator kemampuan koneksi matematis yang ketiga yakni memahami hubungan matematika dengan kehidupan sehari-hari dimana subjek dapat mengartikan dan memahami soal yang berhubungan dengan kehidupan nyata atau sehari-hari.

Subjek KA yang termasuk dalam kelompok gaya kognitif Field Intermediate (FDI) dapat memenuhi indikator kemampuan koneksi yang pertama yakni mengenali ide dan menggunakan ide untuk membuat model matematika. Menyebutkan apa yang diketahui dan apa yang ditanyakan pada 
soal. Membuat model matematika terlebih dahulu sebelum mengerjakan soal agar dapat mempermudah dalam menyelesaikan soal. Subjek belum dapat memenuhi indikator kemampuan koneksi matematis yang kedua yakni membuat hubungan antar konsep yang satu dengan konsep yang lainnya dalam menyelesaikan masalah dilihat dari langkah-langkah yang diambil subjek dalam menyelesaikan soal kedua sudah benar dan sistematis tetapi subjek masih mengalami kesalahan dalam menghitung sedangkan untuk soal pertama sudah benar dan sistematis. Hasil dari jawaban menunjukkan bahwa dapat memahami konsep keliling persegi panjang, luas persegi panjang dan jajar genjang, persentase, dan mean pada statistika tetapi belum memahami konsep operasi hitung aljabar karena mengalami kesalahan perhitungan pada bagian operasi hitung aljabar. Subjek dapat memenuhi indikator kemampuan koneksi matematis yang ketiga yakni memahami hubungan matematika dengan kehidupan sehari-hari, yaitu subjek dapat mengartikan dan memahami soal yang berhubungan dengan kehidupan nyata atau sehari-hari.

Subjek SW yang termasuk dalam kelompok gaya kognitif Field Dependent (FD) belum dapat memenuhi indikator kemampuan koneksi matematis yang pertama yakni mengenali ide dan menggunakan ide untuk membuat model matematika, yaitu tidak dapat menyebutkan apa yang diketahui dan apa yang ditanyakan pada soal, tidak dapat membuat model matematika terlebih dahulu sebelum mengerjakan soal. Subjek belum dapat memenuhi indikator kemampuan koneksi matematis yang kedua yakni membuat hubungan antar konsep yang satu dengan konsep yang lainnya dalam menyelesaikan masalah dilihat dari langkah-langkah yang diambil subjek dalam menyelesaikan kedua soal belum benar. Hasil dari jawaban menunjukkan bahwa belum dapat memahami konsep operasi hitung aljabar, keliling persegi panjang, luas persegi panjang dan jajar genjang, persentase, dan statistika. Subjek belum dapat memenuhi indikator kemampuan koneksi matematis yang ketiga yakni memahami hubungan matematika dengan kehidupan sehari-hari, yaitu subjek belum dapat mengartikan dan memahami soal yang berhubungan dengan kehidupan nyata atau sehari-hari, dan merasa kebingungan dengan langkahlangkah yang harus diambil dalam menyelesaikan soal.

Subjek ID yang termasuk dalam kelompok gaya kognitif Field Dependent (FD) belum dapat memenuhi indikator kemampuan koneksi matematis yang pertama yakni mengenali ide dan menggunakan ide untuk membuat model matematika. Tidak dapat menyebutkan apa yang diketahui dan apa yang ditanyakan pada soal. Tidak dapat membuat model matematika terlebih dahulu 
sebelum mengerjakan soal. Subjek belum dapat memenuhi indikator kemampuan koneksi matematis yang kedua yakni membuat hubungan antar konsep yang satu dengan konsep yang lainnya dalam menyelesaikan masalah dilihat dari langkah-langkah yang diambil subjek dalam menyelesaikan kedua soal belum benar. Hasil dari jawaban menunjukkan bahwa belum memahami konsep operasi hitung aljabar, bangun datar, persentase dan statistika. Subjek belum dapat memenuhi indikator kemampuan koneksi matematis yang ketiga yakni memahami hubungan matematika dengan kehidupan sehari-hari, dalam hal ini subjek belum dapat mengartikan dan memahami soal yang berhubungan dengan kehidupan nyata atau sehari-hari, dan merasa kebingungan dengan langkah-langkah yang harus diambil dalam menyelesaikan soal.

Subjek SW dan ID kelompok gaya kognitif Field Dependent (FD) belum mencapai indikator memahami hubungan dengan kehidupan sehari-hari. Hal ini selaras dengan penelitian yang dilakukan oleh Ariawan dan Nufus (2017) bahwa subjek dengan gaya kognitif Field Dependent (FD) belum dapat menghubungkan dengan kehidupan sehari-hari. Hasil penelitan ini juga selaras dengan hasil penelitian yang dilakukan Sari (2017) bahwa subjek Field Independent (FI) dapat memahami hubungan dengan kehidupan sehari-hari sedangkan subjek Field Dependent (FD) belum dapat memahami hubungan dengan kehidupan sehari-hari.

\section{SIMPULAN}

Gaya kognitif Field Independent (FI) memiliki kemampuan dalam menyelesaikan masalah yang berbeda-beda, ada subjek yang dapat memenuhi ketiga indikator kemampuan matematis ada pula subjek yang hanya memenuhi dua indikator kemampuan matematis. Subjek yang hanya memenuhi dua indikator kemampuan matematis, tidak dapat memenuhi indikator dalam memahami bagaimana ide-ide matematika saling berhubungan. Hal ini menunjukkan bahwa siswa yang berada pada kelompok gaya kognitif yang sama memiliki kemampuan koneksi matematis yang sama. Subjek dengan gaya Kognitif Field Intermediate (FDI) dapat memenuhi dua indikator kemampuan koneksi matematis. Subjek mampu mengenali dan menggunakan hubungan antar ide akan tetapi subjek kurang dapat memahami bagaimana ide-ide matematika saling berkaitan. Subjek mampu memahami hubungan matematika dengan kehidupan sehari-hari. Subjek dengan gaya kognitif Field Dependent (FD) belum dapat memenuhi ketiga indikator dari kemampuan koneksi matematis. Subjek belum mampu dalam mengenali dan menggunakan 
hubungan antar ide pada matematika, memahami bagaimana ide-ide matematika saling berhubungan, dan memahami hubungan matematika dengan kehidupan sehari-hari.

\section{DAFTAR PUSTAKA}

Ariawan, R., \& Nufus, H. (2017). Profil kemampuan koneksi matematis mahasiswa dalam menyelesaikan masalah pada mata kuliah Kalkulus 1 Ditinjau Berdasarkan Gaya Kognitif. Suska Journal of Mathematics Education, 3(2), 102-110. Retrieved from https://www.researchgate.net/publication/323872135_Profil_Kemamp uan_Koneksi_Matematis_Mahasiswa_dalam_Menyelesaikan_Masalah_ pada_Mata_Kuliah_Kalkulus_1_ditinjau_berdasarkan_Gaya_Kognitif

Fajriyah, N., \& Suseno, A. A. (2014). Kemampuan siswa sekolah menengah pertama dalam menyelesaikan masalah matematika berdasarkan gaya kognitif. Jurnal Pendidikan Matematika, 2(1), 12-21. Retrieved from https:// ppjp.ulm.ac.id/journal/index.php/edumat/article/view/584/ 498

Guisande, M. A., Paramo, M. F., Tinajero, C., \& Almeida, L. S. (2007). Field dependence-independence (FDI) cognitive style: An analysis of attentional functioning. Psikotema, 19(4), 572-577. Retrieved from https://www.redalyc.org/pdf/727/72719405.pdf

Kusmanto, H., \& Marliyana, I. (2014). Pengaruh pemahaman matematika terhadap kemampuan koneksi matematis siswa kelas VII semester genap SMP Negeri 2 Kasokandel Kabupaten Majalengka. Eduma: Mathematics Education Learning and Teaching, 3(2), 61-75. Retrieved from http://www.syekhnurjati.ac.id/jurnal/index.php/eduma/article/vie $\mathrm{w} / 56$

National Council of Teachers Mathematics. (2000). Principle and standart for school mathematics. Reston, VA: NCTM.

Ngilawajan, D. A. (2013). Proses berpikir siswa dalam memecahkan masalah matematika materi turunan ditinjau dari gaya kognitif field independent dan field dependent. Pedagogia, 2(1), 71-83. Retrieved from http://ojs.umsida.ac.id/index.php/pedagogia/article/view/48/54

Romli, M. (2016). Profil koneksi matematis siswa perempuan sma dengan kemampuan matematika tinggi dalam menyelesaikan masalah matematika. Jurnal Ilmiah Pendidikan Matematika, 1(2), 145-157. Retrieved 
from https://media.neliti.com/media/publications/90941-ID-profilkoneksi-matematis-siswa-perempuan.pdf

Sari, A. S. (2017). Kemampuan koneksi matematika siswa pada materi teorema pythagoras ditinjau dari gaya kognitif. Universitas Muhammadiyah Surakarta. Retrieved from http:/ / eprints.ums.ac.id/51242/1/NASKAH PUBLIKASI.pdf

Sari, O. S., Yusmin, E., \& Nursangaji, A. (2018). Kemampuan koneksi matematis siswa ditinjau dari gaya kognitif pada materi persegi panjang di SMP. JIPP, 7(6). $\quad$ Retrieved from http://jurnal.untan.ac.id/index.php/jpdpb/article/view/26060/75676 577030

Sugiarti, S., \& Basuki. (2014). Pengaruh model pembelajaran berbasis masalah terhadap kemampuan koneksi matematika siswa dalam pembelajaran matematika. Jurnal Pendidikan Matematika, 3(3), 151-158. Retrieved from https://media.neliti.com/media/publications/226603-pengaruhmodel-pembelajaran-berbasis-mas-c45daf56.pdf

Sugiman. (2008). Koneksi matematik dalam pembelajaran matematika di Sekolah Menengah Pertama. Pythagoras, 4(1), 56-66. Retrieved from https://journal.uny.ac.id/index.php/pythagoras/article/view/687/55 0

Ulya, H. (2015). Hubungan gaya kognitif dengan kemampuan pemecahan masalah matematika siswa. Jurnal Konseling Gusjijang, 1(2). Retrieved from

http://jurnal.umk.ac.id/index.php/gusjigang/article/view/410/442

Ulya, H., Kartono, \& Retnoningsih, A. (2014). Analysis of mathematics problem solving ability of Junior High School students viewed from students' cognitive style. International Journal of Education and Research, 2(10), 577582. Retrieved from http://icmseunnes.com/2015/wpcontent/uploads/2015/10/1.pdf

Usodo, B. (2011). Profil intuisi mahasiswa dalam memecahkan masalah matematika ditinjau dari gaya kognitif field dependent dan field independent (pp. 96-172).

Witkin, H. A., Moore, C. A., Goodenough, D. R., \& Cox, P. W. (1977). Fielddependent and field-independent cognitive styles and their educational 
implication. Review of educational research winter, 47(1), 1-64. Retrieved from https://onlinelibrary.wiley.com/doi/abs/10.1002/j.23338504.1975.tb01065.x

Yanirawati, S., Nilawasti, \& Mirna. (2012). Pembelajaran dengan pendekatan konstektual disertai tugas peta pikiran untuk meningkatkan kemampuan koneksi matematika siswa. Jurnal Pendidikan Matematika, 1(1), 1-7. $\quad$ Retrieved from http:/ / ejournal.unp.ac.id/students/index.php/pmat/article/view/114 $7 / 839$

Yousefi, M. (2011). Cognitive style and EFL learner's listening comprehension ability. Indonesian Journal of Applied Linguistics, 1(1), 73-83. Retrieved from http:/ / ejournal.upi.edu/index.php/IJAL/article/view/100/64 